\title{
A review on strategies to optimize metabolic stages of anaerobic digestion of municipal solid wastes towards enhanced resources recovery
}

\author{
Edwin N. Richard ${ }^{1,2^{*}}$, Askwar Hilonga ${ }^{3}$, Revocatus L. Machunda ${ }^{1}$ and Karoli N. Njau ${ }^{1}$
}

\begin{abstract}
Recently, there are increased efforts by municipals and researchers to investigate the potential of utilizing municipal solid wastes (MSW) for resources recovery. In many parts of developing countries, MSW is mostly collected for disposal with little emphasis on resources recovery. However, the MSW has high organic and moisture contents, and are suitable substrates for anaerobic digestion (AD) process to recover biogas for energy and digestate which can be used as fertilizers or for soil amendments. Resources recovery from the AD process consists of four metabolic stages; hydrolysis, acidogenesis, acetogenesis, and methanogenesis. These metabolic stages can be affected by several factors such as the nature of substrates, accumulation of volatile fatty acids, and ammonia inhibition. In this review, different optimization strategies towards resources recoveries such as pre-treatment, codigestion, trace elements supplementation, optimization of key parameters and the use of granular activated carbon are discussed. The review reveals that the currently employed optimization strategies fall short in several ways and proposes the need for improvements.
\end{abstract}

Keywords: Municipal solid wastes, Resource recovery, Anaerobic digestion

\section{Introduction}

By the year 2012, about 1300 Mt of municipal solid wastes (MSW) were being generated annually, worldwide [1]. The MSW generation rate is projected to increase and could reach over 2000 Mt by 2025, of which more than $40 \%$ will be organic $[1,2]$. Among the factors associated with this increase include; population increase, increased urbanization rates, industrialization, economic growth, and changing food habits and consumption patterns [3, 4]. Currently, MSW causes a management burden for municipals, some of which fail to collect all the wastes produced. In most developing countries, MSW management entails the collection, transportation, and disposal with little or no emphasis

\footnotetext{
* Correspondence: richarde@nm-aist.ac.tz

${ }^{1}$ Department of Water and Environmental Science and Engineering, Nelson Mandela African Institution of Science and Technology, 23311 Arusha, Tanzania

2Department of Water Resources Engineering, University of Dar es Salaam, 16103 Dar es Salaam, Tanzania

Full list of author information is available at the end of the article
}

on resources recovery. The efficient and effective MSW management requires among other things, routine bin collections, proper route-planning, waste separation as well as appropriate waste collection schedules [5].

In developing countries, the transfer and transportation of MSW are affected by many factors including inaccessible roads, poor financial management, outdated machinery and equipment and lack of information about the waste collection schedules $[6,7]$. Furthermore, the very low budgetary allocations by local government authorities can manage only a small percentage of MSW. Consequently, waste generators resort to crude dumping of wastes in unauthorized sites [8-10]. Hoornweg and Bhada-Tata [11] found that low-income countries have a low wastes collection ratio of about $41 \%$ as compared to 98\% in high-income countries. This poor MSW management in developing countries is further exacerbated by rapid urbanization especially in slums and other unplanned areas, where there is inadequate infrastructure to facilitate waste-collection services. In countries like 
Ghana and Nigeria, less than $20 \%$ of solid wastes are properly managed and approximately $80 \%$ is disposed of through crude dumping [12].

In Dar es Salaam, Tanzania's largest city, about more than $5000 \mathrm{t}$ of daily solid wastes are generated but only $40 \%$ of these wastes are collected by municipal councils in partnership with private sectors for disposal [13]. Such inadequate MSW disposal can affect human health through direct exposure or consumption of contaminated foods $[14,15]$. For instance, some diseases such as diarrhoea, dengue fever, and malaria have been linked to poor solid wastes management practices [16]. Collection of wastes for recovery of resources such as biogas and soil conditioners by anaerobic digestion (AD) processes can be a viable option in such circumstances. Furthermore, the recovered products can be a supplementary source of energy and fertilizers and can be sold to offset the costs required for managing MSW.

The purpose of this review is to update our knowledge of the AD process for MSW and strategies to optimize it. The review further evaluates resources recovery options from $\mathrm{AD}$ processes and provides some future perspectives concerning these strategies for effective MSW management. The emphasis to deal with MSW in cities is quickly gaining traction. This review shows that $\mathrm{AD}$ systems can be used for alternative MSW management and high-value products can be derived from the process.

\section{MSW generation and compositions}

Although the definition of MSW varies among scholars, in general, it covers all solid wastes generated in community places such as residential, commercial, and institutions, excluding the hazardous wastes [17]. Whereas waste generation data are available in most developed countries, in developing countries, and particularly in sub-Saharan Africa, such data are scarce [11]. Comparison of available waste generation data between developed and developing countries shows that the generation rates are higher in developed than in developing countries $[3,18]$. The generation also varies among cities and towns in both developed and developing countries.
In developing countries, the generated wastes are rich in organics and have high moisture content (MC). Reports show that the MC composition of wastes in developing and developed countries range between 50 and $70 \%$ and $20-30 \%$ respectively $[19,20]$. The high organic and $\mathrm{MC}$ of wastes in developing countries make composting or AD suitable treatment options for resource recovery processes [21]. The global waste streams (Table 1) comprises of six waste categories of which $46 \%$ are organic waste fractions [11]. The higher percentage of organics in the global waste stream further suggests that MSW has a high potential for resources recovery. The MSW in developed countries also has high calorific values as compared to the wastes in developing countries (Table 2). These differences can be attributed to the differences in waste sorting programs. Whereas sorting programs are widely applied in developed countries, less sorting is done in developing countries which leave a lot of inert materials in MSW [22, 23].

Table 2 indicates the various calorific values of MSW which demonstrate that MSW has a high potential for energy recovery [18, 22-28]. The lack of wasteseparation programs in most cities of developing countries limits the utilization of AD technology for MSW management. Therefore, preferences are given to either incineration or landfills with limited resources recovery from the wastes. Considering the nature of wastes and the multiple benefits $\mathrm{AD}$ can offer, there is a need to identify strategies of improving waste-sorting programs in these countries. In countries where segregation programs exist, resources such as biogas and composts are recovered from MSW to reduce the wastes that could otherwise end in landfills and incineration [6]. AD thus offers the recovery of resources such as biogas for energy and effluent slurry for soil conditioners with less environmental repercussions.

\section{The AD process}

The AD process comprises of a series of metabolic stages namely; hydrolysis, acidogenesis, acetogenesis, and methanogenesis which are further described in this section.

Table 1 Typical global waste composition and sources [11]

\begin{tabular}{lll}
\hline Composition & $\%$ & Sources \\
\hline Organic & 46 & Food scraps, yard (leaves, grass, brush) waste, wood, process residues \\
Paper & 17 & $\begin{array}{l}\text { Paper scraps, cardboard, newspapers, magazines, bags, boxes, wrapping paper, telephone books, } \\
\text { shredded paper, paper beverage cups }\end{array}$ \\
Plastic & 10 & $\begin{array}{l}\text { Bottles, packaging, containers, bags, lids, cups } \\
\text { Glass }\end{array}$ \\
Metal & 5 & Bottles, broken glassware, light bulbs, coloured glass \\
Others & 4 & Cans, foil, tins, non-hazardous aerosol cans, appliances (white goods), railings, bicycles
\end{tabular}


Table 2 Compositions of municipal solid wastes in different cities around the world

\begin{tabular}{|c|c|c|c|c|c|c|c|c|}
\hline City & Organic (\%) & Paper (\%) & Glass (\%) & Plastic (\%) & Metal (\%) & Others (\%) & Calorific value $\left(\mathrm{MJ} \mathrm{kg}^{-1}\right)$ & Ref. \\
\hline Berlin (German) & 15 & 20 & 7 & 23 & 2 & 33 & - & [18] \\
\hline Dhanbad (India) & 75 & 0.6 & 0.5 & 20.7 & 0.3 & 2.9 & $10.7-13.0$ & [22] \\
\hline Australia (Greater Brisbane) & 53.3 & 13 & 4.2 & 14.7 & 2.7 & 12.1 & $7.8-10.7$ & [23] \\
\hline Arusha (Tanzania) & 67 & 11 & 4 & 7 & 1 & 10 & 12.42 & [24] \\
\hline Nairobi (Kenya) & 58.5 & 11.3 & - & 13.8 & - & 16.4 & 12.48 & [25] \\
\hline Algeria (country) & 62 & 9 & 1 & 12 & 2 & 14 & $5.86-6.69$ & [26] \\
\hline Kathmandu (Nepal) & 71 & 7.5 & 1.3 & 12 & 0.5 & 7.7 & - & [27] \\
\hline Mende, Lozère, (France) & 29.6 & 23.3 & 4.2 & 14.8 & 5.4 & 22.9 & - & [28] \\
\hline
\end{tabular}

\section{Hydrolysis}

Hydrolysis is the first stage of the $\mathrm{AD}$ process where complex molecular compounds such as carbohydrates, proteins, and fatty acids are transformed into simpler and soluble molecular compounds such as sugars, amino acids and fatty acids [29]. Equation (1) represents the overall reaction in this stage.

$$
\left(\mathrm{C}_{6} \mathrm{H}_{12} \mathrm{O}_{6}\right)_{\mathrm{x}}+\mathrm{H}_{2} \mathrm{O} \rightarrow \times\left(\mathrm{C}_{6} \mathrm{H}_{12} \mathrm{O}_{6}\right)
$$

Microorganisms which are responsible for hydrolysis release extracellular enzymes which cause the transformation to occur [30]. The hydrolysis of complex organic compounds such as lignocelluloses materials is very slow and is the rate-limiting step during the AD process [31-33]. Therefore, investigations towards improving the hydrolysis step are among the strategies to optimize the AD process. Different techniques are used to improve the hydrolysis process to enhance resources recovery from organic fraction municipal solid wastes (OFMSW) [34-39] as discussed in section 3 and summarized in Table 3.

\section{Acidogenesis and acetogenesis}

In the second stage of the AD process which is acidogenesis, a large group of facultative and obligate anaerobic bacteria converts the products of hydrolysis into other forms to be used in subsequent phases. For instance, sugars, amino acids, and fatty acids are converted into organic acids or volatile fatty acids (VFAs), alcohols, and some inorganic compounds such as $\mathrm{CO}_{2}, \mathrm{H}_{2}, \mathrm{H}_{2} \mathrm{~S}$ and $\mathrm{NH}_{3}$ [33]. Equations (2), (3) and (4) represent the reactions in this stage.

$$
\begin{aligned}
& \mathrm{C}_{6} \mathrm{H}_{12} \mathrm{O}_{6} \leftrightarrow 2 \mathrm{CH}_{3} \mathrm{CH}_{2} \mathrm{OH}+2 \mathrm{CO}_{2} \\
& \mathrm{C}_{6} \mathrm{H}_{12} \mathrm{O}_{6}+2 \mathrm{H}_{2} \leftrightarrow 2 \mathrm{CH}_{3} \mathrm{CH}_{2} \mathrm{COOH}+2 \mathrm{H}_{2} \mathrm{O} \\
& \mathrm{C}_{6} \mathrm{H}_{12} \mathrm{O}_{6} \rightarrow 3 \mathrm{CH}_{3} \mathrm{COOH}
\end{aligned}
$$

Acetogenesis is the third stage of the anaerobic metabolic stage where acetogenic bacteria convert the products of acidogenesis into acetate, hydrogen and carbon

\begin{tabular}{|c|c|c|c|c|}
\hline Strategy & Substrates & $\begin{array}{l}\text { AD } \\
\text { conditions }\end{array}$ & Results & Ref. \\
\hline $\begin{array}{l}\text { Mechanical (Bead milling at } \\
1000 \text { rpm) }\end{array}$ & $\begin{array}{l}\text { OFMSW (Food } \\
\text { Wastes) }\end{array}$ & Batch, $37^{\circ} \mathrm{C}$ & $\begin{array}{l}\text { Particle size reduction from } 0.8 \text { to } 0.7 \mathrm{~mm} \text { improved hydrolysis step and } \\
\text { increased methane yields by } 28 \% \text { at } 1000 \mathrm{rpm}\end{array}$ & {$[34]$} \\
\hline Thermal pre-treatment (at $65^{\circ} \mathrm{C}$ ) & $\begin{array}{l}\text { OFMSW, sewage, } \\
\text { and leachates }\end{array}$ & Batch, $37^{\circ} \mathrm{C}$ & $\begin{array}{l}\text { Thermal pre-treatment at } 65^{\circ} \mathrm{C} \text { accelerated hydrolysis stage and increased } \\
\text { biogas yields by } 7 \%\end{array}$ & {$[35]$} \\
\hline $\begin{array}{l}\text { Thermal pre-treatment } \\
\text { (Steam explosion) }\end{array}$ & $\begin{array}{l}\text { OFMSW and citrus } \\
\text { wastes }\end{array}$ & Batch, $55^{\circ} \mathrm{C}$ & $\begin{array}{l}\text { The steam pretreated citrus wastes co-digested with MSW had a higher } \\
\text { methane yield of } 0.53 \mathrm{~m}^{3} \mathrm{~kg}^{-1} \mathrm{VS}^{-1} \text { which was } 426 \% \text { higher than the } \\
\text { corresponding untreated substrates }\end{array}$ & [36] \\
\hline $\begin{array}{l}\text { Chemical }(5 \mathrm{~N} \mathrm{NaOH} \text { and } 5 \mathrm{~N} \mathrm{KOH} \\
\left.\text { at } \mathrm{pH} 13 \text { and temp } 80^{\circ} \mathrm{C}\right)\end{array}$ & $\begin{array}{l}\text { OFMSW (kitchen } \\
\text { wastes) }\end{array}$ & $\begin{array}{l}\text { Batch, } \\
35^{\circ} \mathrm{C}, 90 \\
\text { rpm }\end{array}$ & $\begin{array}{l}\text { The pretreatment of OFMSW with } 5 \mathrm{~N} \mathrm{NaOH} \text { and } 5 \mathrm{~N} \mathrm{KOH} \text { at a retention } \\
\text { time of } 10 \mathrm{~d} \text { increased the solubility of OFMSW and enhanced the biogas } \\
\text { increase by } 18 \text { and } 30 \% \text { respectively as compared with the untreated } \\
\text { OFMSW }\end{array}$ & [37] \\
\hline Microbial (wood-rotting fungi) & $\begin{array}{l}\text { chestnut and hay } \\
\text { leaves }\end{array}$ & $\begin{array}{l}\text { Batch, 37- } \\
38^{\circ} \mathrm{C}\end{array}$ & $\begin{array}{l}\text { The biogas production was enhanced by } 15 \% \text { as compared to the } \\
\text { untreated substrates }\end{array}$ & {$[38]$} \\
\hline $\begin{array}{l}\text { Microbial (white-rot fungi at } 60^{\circ} \mathrm{C} \text { ) } \\
\text { moisture content) }\end{array}$ & Yard trimmings & Batch, $37^{\circ} \mathrm{C}$ & $\begin{array}{l}\text { Pre-treatment of yard-trimmings with Ceriporiopsis subvermispora, } \\
\text { white-rot fungi at } 60 \% \text { moisture content enhanced methane production } \\
\text { by } 106 \%\end{array}$ & [39] \\
\hline
\end{tabular}
dioxide $[29,40]$.The overall reactions in this stage are represented by Eqs. (5), (6) and (7).

Table 3 Summary of organic fraction municipal solid wastes optimizing pretreatment conditions 


$$
\begin{aligned}
& \mathrm{CH}_{3} \mathrm{CH}_{2} \mathrm{COOH}+2 \mathrm{H}_{2} \mathrm{O} \rightarrow \mathrm{CH}_{3} \mathrm{COOH}+\mathrm{CO}_{2} \\
& \quad+3 \mathrm{H}_{2} \\
& \mathrm{C}_{6} \mathrm{H}_{12} \mathrm{O}_{6}+2 \mathrm{H}_{2} \rightarrow 2 \mathrm{CH}_{3} \mathrm{CH}_{2} \mathrm{COOH}+2 \mathrm{H}_{2} \mathrm{O} \\
& \mathrm{CH}_{3} \mathrm{COO}^{-}+4 \mathrm{H}_{2} \mathrm{O} \rightarrow 2 \mathrm{HCO}_{3}^{-}+\mathrm{H}^{+}+4 \mathrm{H}_{2}
\end{aligned}
$$

Different kinds of VFAs such as acetic, propionic, butyric, valeric, formic, and caproic acids are the intermediate products of the second and third stages; acidogenesis and acetogenesis of AD [41, 42]. These VFAs are important while assessing the performance and monitoring of the stability of AD processes [42, 43]. VFA accumulation is usually an outcome of the imbalance between acid producers in acidogenesis phases and acid consumers in subsequent methanogenic phase [44]. High VFA concentrations can also lead to a drop of $\mathrm{pH}$ in the reactors which is unfavorable for the methanogens. Although the AD process can proceed at a wide range of $\mathrm{pH}$ values at different stages, the optimal range for methanogens is $6.5-7.5$ and should be maintained to enhance the activities of these bacteria [45-47]. Therefore sufficient alkalinity is required during the $\mathrm{AD}$ process to counteract instability and system failure in the process [45].

Different VFA inhibition levels have been reported by various authors. For instance, VFA concentrations of between 5800 and $6900 \mathrm{mg} \mathrm{L}^{-1}$ are reported to inhibit the methanogenic activities in the $\mathrm{AD}$ of kitchen wastes [48]. Zhang and Jahng [49] also reported inhibition of methanogenic activities at VFA concentrations of $18,000 \mathrm{mg} \mathrm{L}^{-1}$ in a semicontinuous $\mathrm{AD}$ of food wastes (FW). In another study by Wei et al. [50], it was indicated that in the $\mathrm{AD}$ of FW, methanogenic activities were strongly inhibited at VFA concentrations of $30,000 \mathrm{mg} \mathrm{L}^{-1}$. Similar results were also obtained by Zhang et al. [51] who indicated the same inhibition levels at an organic loading rate of $4.0 \mathrm{~g}$ volatile solids (VS) $\mathrm{L}^{-1}$ $\mathrm{d}^{-1}$ in $\mathrm{AD}$ treatment of FW. According to these findings, VFA inhibition levels depend on many factors including; the type of a substrate, type of reactors and other operating parameters. The use of the $\mathrm{pH}$ adjustment to prevent VFA inhibition though helpful in delaying process failures is a temporary solution and cannot be used to reverse the process imbalances [52]. Therefore, different strategies including addition of trace elements (TE) and use of granular activated carbon (GAC) to improve acidogenesis and acetogenesis phases of $\mathrm{AD}$ process are used [49, 50, 53-58] (Table 4).

\section{Methanogenesis}

Methanogenesis is the final metabolic stage of the $\mathrm{AD}$ process where degradation of organic materials and the formation of biogas can be accomplished mainly by acetotrophic methanogens and hydrogenotrophic methanogens. Usually, hydrogen is in limited supply in $\mathrm{AD}$ systems, and therefore the majority of methane approximately $70 \%$ is derived from acetate and less than $30 \%$ is produced by hydrogenotrophic methanogens [29]. Whereas acetotrophic methanogens degrade acetate to methane and carbon dioxide, hydrogenotrophic methanogens use carbon dioxide and hydrogen to produce methane (Eqs. (8) and (9)). Methane can also be formed from ethanol by substrate oxidation (Eq. (10)), [29, 51].

$$
\mathrm{CH}_{3} \mathrm{COOH} \rightarrow \mathrm{CH}_{4}+\mathrm{CO}_{2}
$$

\begin{tabular}{|c|c|c|c|}
\hline Strategy & Type of feedstock & Influence of the strategy & Ref. \\
\hline $\begin{array}{l}\text { TE } \\
\text { supplementation }\end{array}$ & $\begin{array}{l}\text { Food wastes supplemented with Fe, } \\
\mathrm{Co}, \mathrm{Mo} \text { and } \mathrm{Ni}\end{array}$ & Addition of TEs stopped VFA inhibition & [49] \\
\hline $\begin{array}{l}\text { TE } \\
\text { supplementation }\end{array}$ & $\begin{array}{l}\text { Food wastes supplemented with Fe, } \\
\mathrm{Co} \text {, and } \mathrm{Ni}\end{array}$ & $\begin{array}{l}\text { Addition of TEs gradually decreased VFA inhibition and maintained process stability, } \\
\text { and allowed higher organic loading operations }\end{array}$ & [50] \\
\hline $\begin{array}{l}\text { TE } \\
\text { supplementation }\end{array}$ & $\begin{array}{l}\text { Food wastes supplemented with Se } \\
\text { and Co }\end{array}$ & $\begin{array}{l}\text { Se and Co supplementation in food wastes digestion prevented VFA accumulations, } \\
\text { increased methane yields and resulted in stable operations }\end{array}$ & [53] \\
\hline Co-digestion & co-digestion of FW (83\%) and PW (17) & $\begin{array}{l}\text { The highest concentrations of TE in piggery wastewater almost doubled the } \\
\text { methane production and prevented VFA accumulations }\end{array}$ & [54] \\
\hline Co-digestion & $\begin{array}{l}\text { Food waste }(66.7 \%) \text { mixed with cattle } \\
\text { manure }(33.3 \%)\end{array}$ & $\begin{array}{l}\text { TE available in cattle manure; Mg (4.99\%), Ca (2.27\%), Mn (950 ppm) and Zn ( } 250 \\
\text { ppm) increased total methane yield by } 42 \%\end{array}$ & [55] \\
\hline $\begin{array}{l}\text { GAC } \\
\text { supplementation }\end{array}$ & $\begin{array}{l}\text { Synthetic wastewater supplemented } \\
\text { with coal-based GAC }\end{array}$ & $\begin{array}{l}\text { GAC supplementation enhanced methane productions, biomass growth, and } \\
\text { acclimatization of microorganisms }\end{array}$ & [56] \\
\hline $\begin{array}{l}\text { GAC } \\
\text { supplementation }\end{array}$ & $\begin{array}{l}\text { VFAs (acetate, propionate, and } \\
\text { butyrate) supplemented with GAC }\end{array}$ & GAC addition enhanced VFA degradation and increased methane yields & [57] \\
\hline $\begin{array}{l}\text { GAC } \\
\text { supplementation }\end{array}$ & OFMSW supplemented with GAC & $\begin{array}{l}\text { GAC supplementation increased syntrophic associations between bacteria and } \\
\text { methanogens }\end{array}$ & [58] \\
\hline
\end{tabular}

$$
\mathrm{CO}_{2}+4 \mathrm{H}_{2} \leftrightarrow \mathrm{CH}_{4}+2 \mathrm{H}_{2} \mathrm{O}
$$

Table 4 Summary of results from trace elements and granular activated carbon supplementation in the anaerobic digestion process 


$$
2 \mathrm{CH}_{3} \mathrm{CH}_{2} \mathrm{OH}+\mathrm{CO}_{2} \rightarrow \mathrm{CH}_{4}+2 \mathrm{CH}_{3} \mathrm{COOH}
$$

\section{Strategies to optimize the anaerobic digestion process of municipal solid wastes}

Different strategies can be used to optimize metabolic stages of $\mathrm{AD}$ process for resource recovery from OFMSW as summarized in Fig. 1.

\section{Optimizing the hydrolysis phase}

Different pre-treatment methods including mechanical, thermal, chemical, and biological treatment are used to improve the hydrolysis stage of AD of OFMSW. A summary of the pros and cons of each of the pretreatment options is provided in Table 5. Mechanical pre-treatment which mainly focuses on the reduction of particle size and crystallinity nature of lignocellulosic materials has widely been used compared to the other pre-treatment options. Izumi et al. [34] showed that particle size reduction of FW by bead-milling improved the hydrolysis step and enhanced biogas production. However, excessive particle size reduction resulted in VFA accumulation and decreased biogas production. Mechanical pre-treatment has the disadvantage of high power requirement, especially when treating lignocellulosic-based OFMSW [59]. Among the mechanical pretreatments methods for OFMSW, the simplest are maceration, sonication, and high-pressure homogenizer [60].
The application of thermal pre-treatment can be employed to enable the conversion of lignocellulosic OFMSW before AD process to enable the conversion of lignocellulosic OFMSW before $\mathrm{AD}$ process. The high temperatures enable the melting of lignin and are freed from shielding the cellulose and hemicelluloses framework from chemical or bacteria digestion. This option can be very expensive due to the high heat requirement. However, in the industrial application, the costs can be offset if the generated biogas is used as a source of heat for treatment. The effect of thermal pretreatment on anaerobic co-digestion of OFMSW, leachates, and sludge was investigated using batch experiments [35]. The results indicated an improvement in the hydrolysis step and a $7 \%$ increase of biogas generation. Forgacs et al. [36] assessed the effects of steam pretreatment of citrus waste and MSW. The pretreatment achieved a $426 \%$ increase in methane yield compared to unpretreated substrates.

Chemicals such as alkalis, acids, and ozone have also been used to pre-treat lignocellulosic-based OFMSW. The findings from Liew et al. [31] indicated a $20 \%$ increase of methane yields after pre-treatment of fallen leaves with $3.5 \% \mathrm{NaOH}$ compared to unpretreated ones. Alqaralleh et al. [37] also investigated the pretreatment of OFMSW with $\mathrm{NaOH}$ and $\mathrm{KOH}$ at a retention time of $10 \mathrm{~d}$. The $\mathrm{NaOH}$ and $\mathrm{KOH}$ pre-treatments enhanced the biogas production by 18 and $30 \%$ respectively as

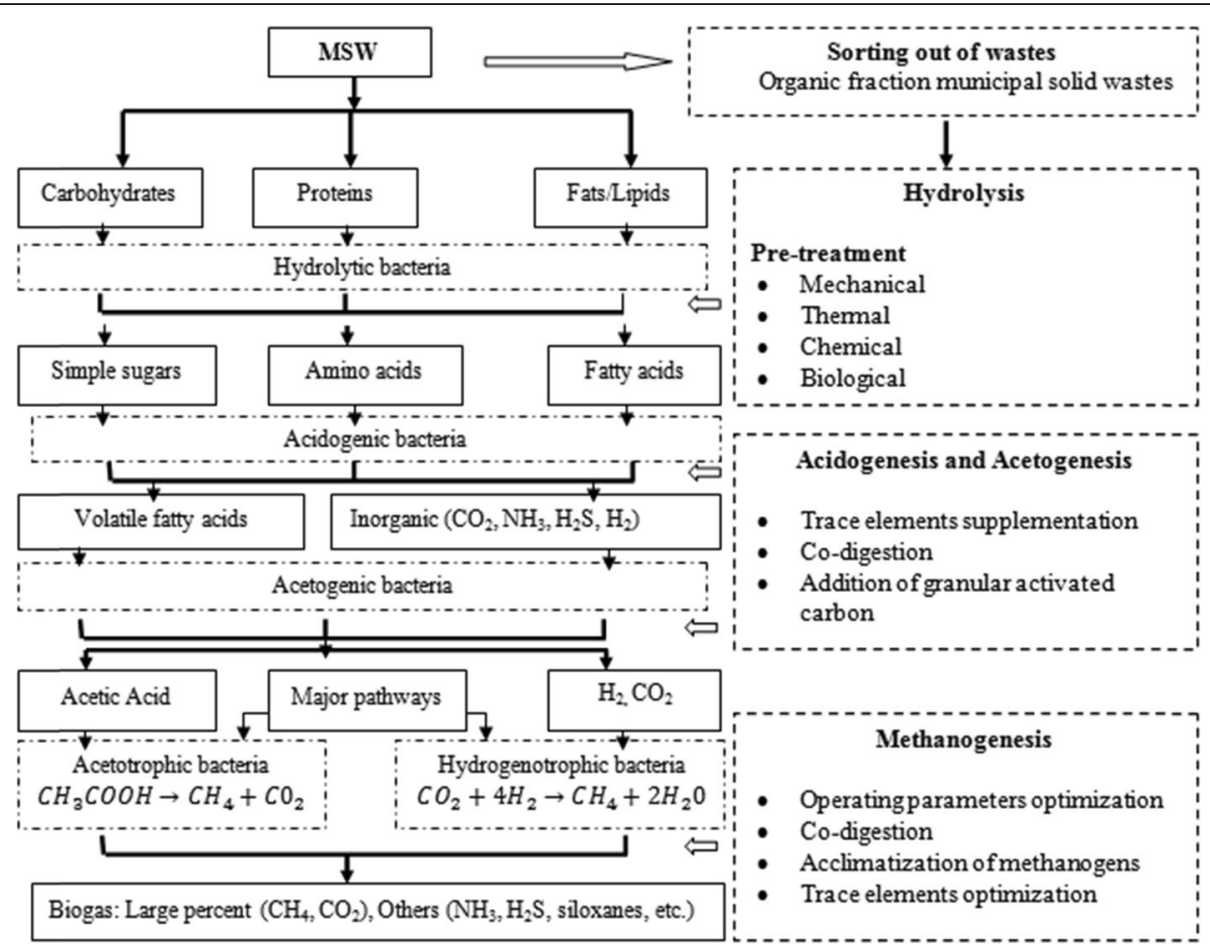

Fig. 1 Strategies to improve metabolic stages of the anaerobic digestion process of organic fraction municipal solid wastes 
Table 5 Summary of pro and cons of pretreatment strategies to optimize the hydrolysis stage

\begin{tabular}{|c|c|c|}
\hline Strategy & Pro & Cons \\
\hline Mechanical & $\begin{array}{l}\text { - Particle size reduction increases the surface area available for } \\
\text { microorganisms resulting in improved anaerobic degradability } \\
\text { - Promotes rapid digestion of lignocellulosic-based OFMSW }\end{array}$ & $\begin{array}{l}\text { - Excessive particle size reductions may result in } \mathrm{pH} \text { decrease } \\
\text { resulting in decreased methane yields } \\
\text { - High energy requirements and the possibility of impurity } \\
\text { contaminations during particle size reductions process }\end{array}$ \\
\hline Thermal & $\begin{array}{l}\text { - Accelerate lignin solubilization of lignocellulosic-based OFMSW } \\
\text { and shortening hydraulic retention time } \\
\text { - Removal of pathogens in substrates with subsequent } \\
\text { enhancement of digestate handling }\end{array}$ & $\begin{array}{l}\text { - High running costs due to high heating energy requirements for } \\
\text { running the process } \\
\text { - High temperatures may result in the creation of chemical bonds } \\
\text { and agglomeration of particles }\end{array}$ \\
\hline Chemical & $\begin{array}{l}\text { - Alkali and acid pretreatment enhances removal of lignin which } \\
\text { enhances better contact of substrates and microorganisms } \\
\text { - Alkali pre-treatment with } \mathrm{NaOH} \text { and } \mathrm{KOH} \text { enhance COD } \\
\text { solubilization of OFMSW which accelerates methane production } \\
\text { - When used at a small scale, chemical pre-treatment has low cap- } \\
\text { ital costs }\end{array}$ & $\begin{array}{l}\text { - Use of chemical pre-treatment may lead to the formation of inhibi- } \\
\text { tory products such as phenolic compounds, furans, and carboxylic } \\
\text { acids which may inhibit the growth of the methanogens } \\
\text { - Acid pre-treatment may lead to the corrosion of equipment which } \\
\text { may be very expensive to repair. } \\
\text { - A high-cost requirement of chemicals in large scale biogas } \\
\text { productions } \\
\text { - Digestate produced may require careful handling due to by- } \\
\text { products formed }\end{array}$ \\
\hline Microbial & $\begin{array}{l}\text { - Facilitates removal of lignin and hemicelluloses degradation of } \\
\text { lignocellulosic-based OFMS which enhances better contact of } \\
\text { substrates and microorganisms } \\
\text { - Due to low or no use of chemicals, there is little corrosiveness } \\
\text { and by-product formation } \\
\text { - Can be applied in milder conditions } \\
\text { - May lead to the production of the safe digestate with minimum } \\
\text { disposal costs } \\
\text { - Considered to be an environmental friend with low capital costs } \\
\text { and energy requirements }\end{array}$ & $\begin{array}{l}\text { - A slow process and hence degradation of lignocellulosic-based } \\
\text { OFMSW may take several weeks to months } \\
\text { - Due to the heterogeneous nature of OFMSW, different specific } \\
\text { enzymes may be required. } \\
\text { - Require sterile environments }\end{array}$ \\
\hline
\end{tabular}

compared to untreated OFMSW. Some of the drawbacks of chemical pre-treatments include the formation of inhibitory products such as phenolic compounds, furans, and carboxylic acids that can inhibit the growth of the methanogenic bacteria [61]. Furthermore, higher amounts of chemicals may be required in large scale biogas production which may increase operating costs. Due to this, the use of chemicals, especially alkalis, is preferred for temporary $\mathrm{pH}$ adjustments during the $\mathrm{AD}$ process to counteract VFA accumulations and maintain process stability $[45,59]$.

The microbial pre-treatments have also been used to treat lignocellulosic OFMSW. Mackulak et al. [38] investigated the effects of pre-treatment of sweet chestnut leaves and hay with Auricularia auricular-judae, whiterot fungi. The results showed that biogas production was enhanced by $15 \%$ compared to non-pretreated substrates. In another study by Zhao et al. [39], the effect of pre-treatment of yard-trimmings with Ceriporiopsis subvermispora, white-rot fungi indicated a $106 \%$ increase in methane yields at $60 \% \mathrm{MC}$ in pre-treated samples as compared to non-pretreated ones. Some of the advantages of microbial pre-treatments include less corrosiveness and formation of less harmful products due to the absence of chemicals [62]. However, microbial pretreatment processes are very slow and require several specific enzymes because of the heterogeneous composition of OFMSW [30, 59].
Whereas thermal and mechanical pre-treatments have widely been applied at industrial scales, microbial and chemical pre-treatments are rarely applied. The use of chemical pre-treatment at industrial levels has high costs implications. However, as the demand for more energy and adequate urban wastes management increase around the globe, all these options can be applied for OFMSW pre-treatment at the industrial scale. Different pretreatment technologies can also be combined upon evaluation on their economic, technical and environmental feasibilities. Furthermore, there is still a need to investigate new pre-treatment options that can be used to improve the hydrolysis process for biogas production. Improvement of the hydrolysis step will facilitate biogas recovery, reduce greenhouse gases emissions, and facilitate low-cost environmental management.

\section{Optimizing the acidogenesis and acetogenesis phases Addition of TE and co-digestion}

Generally, the absence of TE is regarded as one of the contributing factors for process instabilities and process failure in the $\mathrm{AD}$ process. It is believed that the addition of $\mathrm{TE}$ in the $\mathrm{AD}$ process can improve activities of enzymes, growth of methanogens and process stability of the $\mathrm{AD}$ system $[53,63]$. In the AD of OFMSW, TE can be added through co-digestion of OFMSW with substrates that are rich in TE or through direct addition of external TE [51]. Several studies on TE supplementations 
have confirmed that it improves the performance of the AD systems (Table 5). Co-digestion of wastes has advantages of dilution of inhibitory substances, balancing of carbon-to-nitrogen $(\mathrm{C} / \mathrm{N})$ ratio, and improving synergetic effects of microorganisms [64, 65]. Zhang et al. [54] investigated the effects of the co-digestion of FW and piggery wastes (PW) and the results indicated an increase of methane yields to $388 \mathrm{~mL} \mathrm{CH}_{4} \mathrm{~g}^{-1} \mathrm{VS}^{-1}$ which was twice as much as yields generated from mono digestion of FW. The higher concentrations of TE in PW were the key factors for the improved performance in the co-digestion and prevention of VFA inhibitions. Similarly, Zhang et al. [55] studied the effects of co-digestion of FW and cattle manure (CM). The results indicated that the total volume of methane produced was higher in co-digested mixtures as compared to digestion of single FW or CM. The co-digestion of FW and $\mathrm{CM}$ at the ratio of 2:1 had the highest total methane yield, mainly due to the high concentration of $\mathrm{TE}(\mathrm{Mg}, \mathrm{Ca}, \mathrm{Mn}$, and $\mathrm{Zn}$ ) in the mixtures.

Direct supplementation of TE has been studied by several researchers. Banks et al. [53] studied the effects of direct supplementation of selenium (Se) and Cobalt (Co) in the AD process of FW at elevated ammonia concentration and high propionic acid accumulation. The results indicated that $\mathrm{Se}$ and $\mathrm{Co}$ supplementation improved the process stability and prevented process failures. Wei et al. [50] also found that addition of Iron $(\mathrm{Fe}), \mathrm{Co}$, and Nickel $(\mathrm{Ni})$ in the $\mathrm{AD}$ of FW in decreasing VFA inhibition and increasing methane production and process stability of the digesters. Similarly, Zhang and Jahng [49] also indicated that TE supplementation to long term AD of FW resulted in stable operations and prevented VFA accumulations. These findings suggest that the shortage of TE in most of the substrates is one of the contributing factors for VFA accumulations and inhibitions. Future studies on TE should focus on understanding the relationship between microbial activities in response to TE supplementations on OFMSW. This will help to further improve the $\mathrm{AD}$ process and to maximize resources recovery.

\section{Addition of GAC}

Addition of GAC has been used to improve the acidogenesis and acetogenesis phases of the $\mathrm{AD}$ process (Table 5). Due to the pores on their surfaces, GAC can serve purposes such as immobilization of syntrophic microorganisms, adsorption of inhibitors, and promotion of direct interspecies electron transfer in $\mathrm{AD}$ process [66-69]. In a study by Capson-Tojo et al. [40], the addition of GAC on the AD of FW resulted in in enhanced VFA consumption, increased methane production, promoted growth of methanogens and reduced the lag phase. In another study, Lee et al. [56] investigated the influence of GAC on $\mathrm{AD}$ of synthetic wastewater
(SWW). The results indicated that GAC supplementation to SWW enhanced methane production 1.8-fold higher than the reactor with no GAC supplementation. $\mathrm{Xu}$ et al. [57] also studied the effects of GAC on methanogenic degradation of VFAs and the results showed that GAC addition accelerated the degradation of propionate and butyrate under high organic load which subsequently increased methane production. It is believed that high VFA degradation upon GAC supplementation was due to enhanced syntrophic associations between the bacteria. Similarly, Dang et al. [58] indicated that addition of GAC to the AD of OFMSW promoted the growth of bacteria and methanogens, improved VFA degradation, and increased methane production rates. Due to energy shortages and waste management problems, OFMSW holds a sustainable future for biogas production due to their abundance.

Although the use of GAC has been shown to enhance biogas production of OFMSW and other wastes in labscale experiments and at industrial levels in the developed countries, operating biogas plants with GAC requires very strict techniques [70]. Therefore, studies on how to operate biogas plants with GAC in developing countries are still needed. Furthermore, future investigations on new materials with adsorptive or conductive properties that can be used to manufacture GAC are still needed in order to improve the $\mathrm{AD}$ process.

\section{Optimizing the methanogenesis phases}

Ammonia inhibition is a major factor in the methanogenesis stage. During the AD process for biogas production, ammonia is produced from various sources like the breakdown of proteins and amino acids [71]. Under aerobic conditions, ammonia is microbially oxidized to nitrite and nitrate. Consequently, ammonia may accumulate under anaerobic conditions due to the absence of oxygen oxidant. At optimal concentrations, ammonia is important for microbial growth and forms $\mathrm{NH}_{4}\left(\mathrm{HCO}_{3}\right)$ when combined with $\mathrm{CO}_{2}$ and $\mathrm{H}_{2} \mathrm{O}$ which increases the buffering capacity and maintain the stability of the $\mathrm{AD}$ process [72, 73]. At high concentrations, ammonia is toxic to microorganisms and is widely reported to inhibit methanogenic activities [65, 71].

In aqueous anaerobic processes, ammonia exists in two principal forms; unionized ammonia $\left(\mathrm{NH}_{3}\right)$ and ionized ammonia $\left(\mathrm{NH}_{4}{ }^{+}\right)$which together form total ammonia nitrogen (TAN) [74]. $\mathrm{NH}_{3}$ and $\mathrm{NH}_{4}{ }^{+}$exist in equilibrium and are reversible depending on temperature and pH (Eqs. (11) and (12)). The toxic level of ammonia is caused by unionized ammonia due to its capability to penetrate microbial cell membrane leading to disruption of potassium and proton balances.

$$
\left[\mathrm{NH}_{3}\right]+\left[\mathrm{H}^{+}\right] \leftrightarrow\left[\mathrm{NH}_{4}^{+}\right]
$$


$[\mathrm{TAN}]=\left[\mathrm{NH}_{4}^{+}\right]+\left[\mathrm{NH}_{3}\right]$

where, $[\mathrm{TAN}]=$ Total ammonia concentration in $\mathrm{mg} \mathrm{L}^{-}$ ${ }^{1},\left[\mathrm{NH}_{4}^{+}\right]=\mathrm{NH}_{4}{ }^{+}$concentration in $\mathrm{mg} \mathrm{L}^{-1}$, and $\left[\mathrm{NH}_{3}\right]=$ $\mathrm{NH}_{3}$ concentration in $\mathrm{mg} \mathrm{L}^{-1}$

Unionized ammonia and ionized ammonia and ammonium equilibrium constant are related by Eq. (13).

$$
\mathrm{Ka}=\left[\mathrm{NH}_{3}\right]\left[\mathrm{H}^{+}\right] /\left[\mathrm{NH}_{4}{ }^{+}\right]
$$

Where, $\left[\mathrm{H}^{+}\right]=\frac{1}{10^{\mathrm{pH}}}$

Therefore, from Eqs. (11), (12), (13) and (14) the concentration of proportion of $\mathrm{NH}_{3}, \mathrm{NH}_{4}{ }^{+}$to TAN can be given by Eqs. (15) and (16).

$$
\begin{aligned}
& \frac{\left[\mathrm{NH}_{3}\right]}{[\mathrm{TAN}]}=\frac{1}{1+\frac{\left[\mathrm{H}^{+}\right]}{\mathrm{Ka}}} \\
& \frac{\left[\mathrm{NH}_{4}{ }^{+}\right]}{[\mathrm{TAN}]}=\frac{1}{1+\frac{\mathrm{Ka}}{\left[\mathrm{H}^{+}\right]}}
\end{aligned}
$$

where $\mathrm{Ka}$ is equilibrium constant and is a function of the temperature $(\mathrm{T})$. Ji [74] reported the Ka to be given by Eq. (17).

$$
\log _{10} \mathrm{Ka}=0.2976-0.001225 . T-(2835.76 /(T+273.15))
$$

Figure 2 depicts the variations of $\mathrm{NH}_{4}^{+}$and $\mathrm{NH}_{3}$ concentrations with $\mathrm{pH}$ and temperatures of water as calculated from Eqs. (15), (16) and (17). From Fig. 2, at pH 6.5 and temperatures of between 25 and $37^{\circ} \mathrm{C}$, unionized ammonia is almost $0 \%$ and at the temperature of $55^{\circ} \mathrm{C}$, unionized ammonia is almost $5 \%$ indicating less toxicity in AD system. Similarly, at pH 8.5 and temperatures of between 25 and $37^{\circ} \mathrm{C}$, free ammonia is approximately 15 and $30 \%$. At the same $\mathrm{pH}$ of 8.5 but higher temperatures of $55^{\circ} \mathrm{C}$, the concentration of the free ammonia is almost $60 \%$ indicating high toxicity in the $\mathrm{AD}$ systems. It can be concluded that as the $\mathrm{pH}$ and temperature increase, the concentration of the un-ionized ammonia also increases. However, ammonia inhibitory level depends on many factors such as feedstock, microbial community and thus inhibitory investigation studies on different substrates and conditions are required.

While several investigations have tried to improve the methanogenesis step through optimization of single parameters such as temperature or $\mathrm{pH}[75,76]$, it is clear that operation parameters relate to each other and thus optimization study should not only focus single parameters. The methodologies which can be used to optimize and understand the relationship between temperatures, $\mathrm{pH}$ and ammonia concentration in the AD process are thus required.

Other strategies to counteract ammonia inhibition include the blending of feedstock to achieve a favorable $\mathrm{C} / \mathrm{N}$ ratio, acclimatization, and TE optimization $[55,71,77]$. A $\mathrm{C} / \mathrm{N}$ ratio of $20-35: 1$ is often recommended for the $\mathrm{AD}$ process [64]. However, $\mathrm{C} / \mathrm{N}$ ratios vary among various feedstock and so the optimum ratio to improve $\mathrm{AD}$ process stability can be achieved

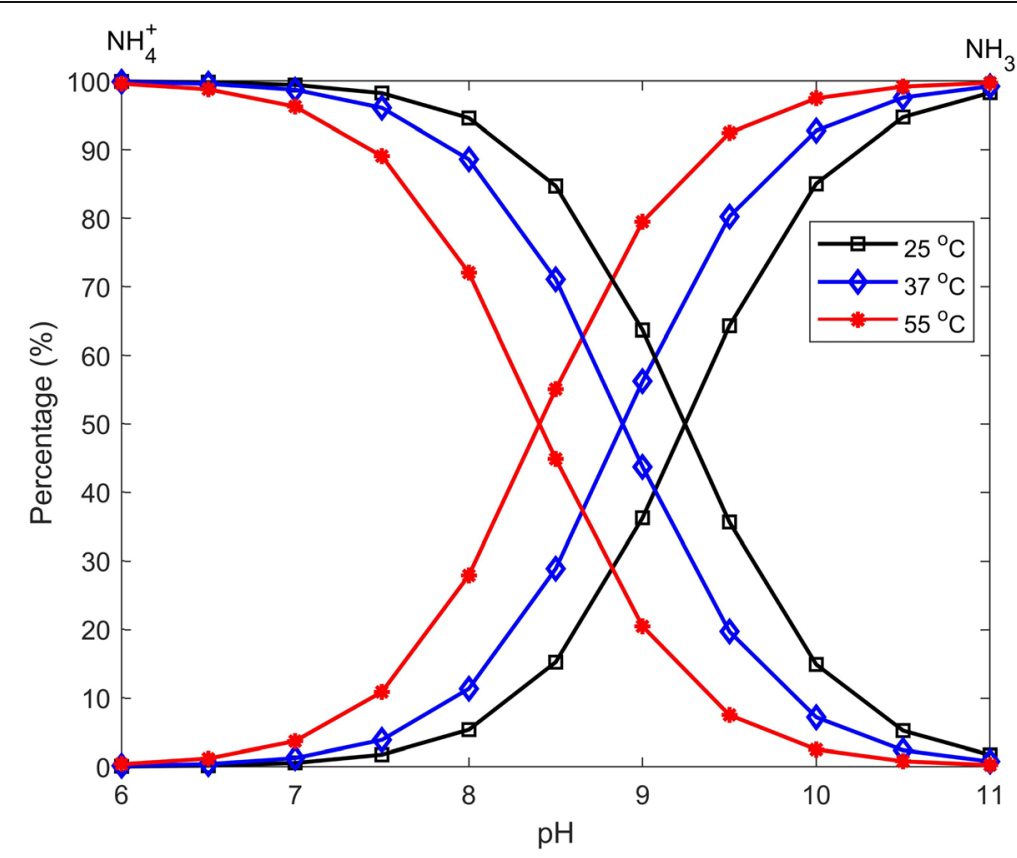

Fig. 2 Variations of un-ionized ammonia and ionized ammonia concentration with $\mathrm{pH}$ and temperature 
through the mixing of substrates with low and high $\mathrm{C} / \mathrm{N}$ ratio [78].

\section{Resources recovery from the AD of MSW}

Globally, industrial applications of the AD process of OFMSW as the main substrate for energy recovery is still not well developed. In most existing large plants, OFMSW has been used as co-substrates to supplement other substrates such as sludge. When AD plants are only for the treatment of wastewater, products such as biogas and digestate are of less value to biogas plant operators and therefore not well utilized. The biogas produced is therefore often self-utilized in the plants and the excess is flared. Similarly, the digestate in most developing countries is of no importance to the operators of the anaerobic digesters who normally discharge it into the sewer lines [45].

Currently, the demand for energy, food security, and urban waste management in most cities around the world is evident. This means that AD-derived products which were previously less valued by operators now need to be recovered to improve energy, environment and agricultural sectors. The global population is expected to reach approximately 10 billion by 2050 and most of this growth which will take place in Africa accompanied by increased energy demands and urban wastes generation [79]. Production and promotion of useful products from OFMSW has the possibility of improving energy production and wastes management. The best way to promote valuable products from the $\mathrm{AD}$ process is through the optimization of the metabolic process so as to maximize the recovery of the derived products.

\section{Utilization of biogas as an energy source}

Biogas can be produced when MSW is digested by microorganisms under anaerobic conditions. Biogas composition is dependent on the waste compositions and is typically comprised of large per cent methane (50-75\%), and carbon dioxide (25-75\%). Biogas also contains a small percentage of hydrogen, hydrogen sulfide, oxygen, ammonia, siloxanes, and aromatic and halogenated compounds $[1,80,81]$. In small scales, biogas can be used to meet energy requirements such as cooking, heating, and lightning [82].

In most urban areas of sub-Saharan Africa, people predominately use wood-fuel for the majority of their cooking needs. Wood is logged in forests far away, transported and sold at a high cost for consumers. Therefore, biogas production from MSW can be used to replace or supplement the traditional cooking wood-fuel. Due to the shortage of energy and the current problems of MSW, the use of a large-scale biogas technology can be a viable solution. Under large scale applications, biogasproducing plants can utilize several types of organic wastes from the livestock waste, food-processing industry, sewage sludge, and MSW to generate electricity [83]. Some of the challenges of using MSW in AD systems for electricity generation include inert impurities in wastes which require particular attention during the processing of wastes [84].

The development of large-scale technology for processing MSW is still in its infancy in most cities of developing countries. However, several studies indicate that MSW of developing countries has an energy potential which can be enhanced to generate electricity. For instance, Al-Hamamre et al. [85] reported that about $387 \mathrm{kt}$ of MSW per year are produced in Jordan of which $42 \%$ are available for energy generation and biogas production. Similarly, in SouthAfrica, a report by Laks [86] indicates that there are about 38 commercial biogas projects in operation, producing about 50-70 MW from different kinds of wastes including MSW.

Upon purification to remove $\mathrm{CO}_{2}, \mathrm{H}_{2} \mathrm{~S}$, water vapour, and other impurities, biogas can be used for many applications. For instance, it can be used as transport fuel injected in natural gas pipelines, combined heat, and power and as a vehicle fuel $[83,87]$. As a result, research on the development of biogas upgrading technologies has gained traction among various scholars all over the globe $[88,89]$.

\section{Utilization of digestate as fertilizer or soil amendment}

The constant application of chemical fertilizers is implicated in problems of soil degradation and environmental pollution [90, 91]. In addition, most developing countries import these fertilizers making their usage expensive [92]. Digestate (or effluent slurry), the product derived from the $\mathrm{AD}$ process can be used to supplement or replace the use of chemical fertilizers. Therefore, large quantities of MSW produced in cities can be processed to valuable products such as digestate that can be used to replenish nutrients in the soil.

Digestate from the AD of MSW is rich in nutrients such as nitrogen, phosphorus, potassium, and TE which are suitable for land applications to improve soil structures $[93,94]$. In the $\mathrm{AD}$ of OFMSW, the digestate may contain up to $50 \%$ organic nitrogen and $50 \%$ ammonia. While ammonia is readily available for plant uptake, organic nitrogen, on the other hand, requires ammonification/mineralization before uptake by plants $[95,96]$. The quality of the digestate depends on several factors such as the nature of the materials to be digested, digestion process, operation temperatures, and retention time [96]. The digestate may contain pathogens, hence, pretreatments may be necessary before discharge or re-use to obtain the quality and safe digestate [97, 98]. The mono-digestion of OFMSW can produce a digestate which is safe to re-use as a fertilizer or for soil 
amendments. However, large scale biogas production can utilize several kinds of wastes including sewage and therefore digestate may not be suitable for direct reuse or discharge.

Anaerobic digestate can either be used as fertilizers or organic amendments depending on the nutrients contained in them. Generally, the higher the percentage of the mineral nitrogen in the digestate relative to organic fraction, the more the waste is suitable for use as fertilizers [99]. Conversely, the lower the per cent of mineral nitrogen fraction relative to the organic the more the digestate is suitable for use as an organic amendment. Apart from the use of a digestate as fertilizer or soil organic amendment, it can also be used as a solid biomass fuel. Kratzeisen et al. [100] investigated the net calorific value of a digestate from a silage maize co-digestion with field crops and animal residue. The results showed that the calorific values were between 15 to $15.8 \mathrm{MJ} \mathrm{kg}^{-1}$, which is higher, compared to wood-fuel. This demonstrated that digestate can be used as alternative woodfuel energy. In summary, digestate can be used in several ways and thus further investigation on the proper way that can bring maximum benefits from the utilization of a digestate is needed.

\section{Environmental and economic evaluations of MSW treatment options}

In order to make decisions on technological selections to treat MSW, several factors must be considered including technical, economic, environmental, sociocultural, political, institutional, organizations and legal aspects of the local environment [101]. However analysis of all factors is often complex in developing countries due to the lack of data, and a few factors like the economic cost $(\mathrm{EcC})$ and environmental cost $(\mathrm{EnC})$ are often used as the basis of these analyses [13, 102, 103]. Table 6 depicts the average $\mathrm{EcC}$ and $\mathrm{EnC}$ costs (in USD) for treating 1 ton of MSW in developing countries for five treatment options as computed by various authors.
Whereas the computation of EcC considers operating costs for the treatment options, $\mathrm{EnC}$ is analyzed based on $\mathrm{CO}_{2}$ emissions from various treatment options. From the comparison table, the negative values indicate an advantage after the adoption of the treatment option. For instance, the recycling and incineration of paper wastes in comparison to the plastic wastes represents an advantage in environment costs due to greater avoided impacts in $\mathrm{CO}_{2}$ emission.

With an average unit of EcC and EnC costs per ton of MSW, the total cost for the total MSW generated in different cities can be estimated and through the use of multi-criteria analysis approach (ELECTRE Method), the best scenarios with optimal EcC and EnC costs can be selected.

Kazuva and Zhang [13] investigated the MSW treatment scenarios with lowest $\mathrm{EcC}$ and $\mathrm{EnC}$ in rapid urban cities of developing countries using Dar es Salaam city in Tanzania as the case study. Using the ELECTRE Method, the best scenarios were found to be; composting for organic wastes, recycling for plastic, paper, glass and other waste to be landfilled. Similar results were obtained by De Medina-Salas et al. [102] who analyzed the lowest $\mathrm{EcC}$ and $\mathrm{EnC}$ MSW treatment scenarios and landfilling in a medium-sized city using the ELECTRE Method. In another study by Qazi et al. [104], waste to energy options for MSW treatment with the lowest $\mathrm{EcC}$ and EnC in Sultanate of Oman were also investigated using the same method and the results indicated that $\mathrm{AD}$ is the best scenario for organic fractions of MSW with low EcC and EnC costs. Due to variations in waste quantities and compositions, different cities can have different best scenarios reflecting the conditions of the concerned locality. Optimization of the $\mathrm{AD}$ process and other treatment options is very crucial and can significantly contribute to the reduction of the $\mathrm{EcC}$ and $\mathrm{EnC}$ of the selected treatment scenarios.

Table 6 Average economic and environmental cost of municipal solid waste treatment options (USD $t^{-1}$ )

\begin{tabular}{|c|c|c|c|c|c|c|c|}
\hline Treatment option & Cost & Organic waste & Plastic & Paper & Glass & Others & Refs \\
\hline \multirow[t]{2}{*}{ Anaerobic digestion } & $\mathrm{EcC}$ & 115.25 & - & - & - & - & \\
\hline & EnC & -0.56 & - & - & - & - & \\
\hline \multirow[t]{2}{*}{ Land filling } & $\mathrm{EcC}$ & 58.25 & 71.10 & 67.25 & 70.32 & 68.33 & [13] \\
\hline & EnC & 0.47 & 0.04 & 0.44 & 0.44 & 0.48 & \\
\hline \multirow[t]{2}{*}{ Incineration } & EcC & - & 20.00 & 20.00 & - & 55.05 & {$[13,102]$} \\
\hline & EnC & - & 1.38 & -0.49 & - & - & \\
\hline \multirow[t]{2}{*}{ Recycling } & $\mathrm{EcC}$ & - & 93.89 & -67.00 & 20.12 & - & {$[102,103]$} \\
\hline & EnC & - & -1.30 & -3.89 & -0.31 & - & \\
\hline \multirow[t]{2}{*}{ Composting } & $\mathrm{EcC}$ & 47.00 & - & - & - & - & {$[102,103]$} \\
\hline & $\mathrm{EnC}$ & 0.09 & - & - & - & - & \\
\hline
\end{tabular}




\section{Conclusions and future perspectives}

This review paper discusses different strategies for optimization of metabolic stages of the AD process, with particular attention to the organic fraction MSW. The four metabolic stages of anaerobic digestion systems and previous studies used to optimize the process have been analyzed. The challenges with the current optimization strategies were pointed out and likely areas for further improvement have also been evaluated.

The available literature reveals that mechanical pretreatment has widely been used to enhance the hydrolysis process. Maceration, sonication, and high-pressure homogenizer are simple mechanical pre-treatment methods that can enhance the solubilization of OFMSW. Although mechanical pre-treatment promotes rapid digestion of lignocellulosic-based OFMSW, it has high power requirements and there is the possibility of contaminations from impurities during the process. Future studies on mechanical pre-treatments should focus on optimizing power consumption and possibilities of abating contaminations during the process. Chemical and microbial pre-treatments are rarely used at industrial applications; however, they can be suitable with other pretreatment technologies. Future studies should similarly focus on evaluations of feasibilities of combining the pre-treatment technologies and investigating of the new pre-treatment technologies.

To optimize the acidogenesis and acetogenesis phases of $\mathrm{AD}$, the addition of $\mathrm{TE}$ and GAC have proven to be successful. The uses of TE and GAC have the advantages of counteracting VFA inhibition to improve process stability, enhancing activities of enzymes and promoting the growth of methanogens. Future studies on TE should focus on investigating the relationship between microbial activities in the digesters in response to TE supplementation on OFMSW. Such studies will help to improve the AD systems to maximize resources recovery. Operating biogas plants with GAC is complicated and requires high-level techniques. Therefore, future studies on GAC should both focus on the identification of new GAC materials and development of simple techniques to operate GAC in developing countries.

With regards to the methanogenesis stages optimization, several techniques including optimization of operating parameters, blending of feedstock to achieve a favorable $\mathrm{C} / \mathrm{N}$ ratios, and acclimatization have widely being applied. This review demonstrates that optimization of a single parameter for controlling ammonia inhibition may be inadequate as parameters relate to each other. Thus, further studies should focus on controlling ammonia inhibitions and understanding how operating parameters are related.

\section{Acknowledgements}

The authors wish to thank the African Development Bank (AFDB) and Nelson Mandela African Institution of Science and Technology (NM-AIST) for financial support. The authors also acknowledge Prof. Tatiana Pogrebnaya and Mr. Geradius Deogratias for their contributions to the review.

Authors' contributions

All authors read and approved the final manuscript.

\section{Funding}

This work was supported by the Nelson Mandela African Institution of Science and Technology (NM-AIST) through the African Development Bank (AFDB).

\section{Availability of data and materials}

All data generated or analyzed during this study are within the submitted manuscript.

\section{Competing interests}

The authors declare they have no competing interests.

\section{Author details}

${ }^{1}$ Department of Water and Environmental Science and Engineering, Nelson Mandela African Institution of Science and Technology, 23311 Arusha, Tanzania. ${ }^{2}$ Department of Water Resources Engineering, University of Dar es Salaam, 16103 Dar es Salaam, Tanzania. ${ }^{3}$ Department of Materials Science and Engineering, Nelson Mandela African Institution of Science and Technology, 23311 Arusha, Tanzania.

Received: 22 April 2019 Accepted: 15 November 2019

Published online: 17 December 2019

\section{References}

1. Kumar A, Samadder SR. A review on technological options of waste to energy for effective management of municipal solid waste. Waste Manag. 2017;69:407-22.

2. Pavi S, Kramer LE, Gomes LP, Miranda LAS. Biogas production from codigestion of organic fraction of municipal solid waste and fruit and vegetable waste. Bioresour Technol. 2017;228:362-7.

3. Kothari R, Kumar V, Pawar NL, Tyagi W. Municipal solid-waste management strategies for renewable energy options. In: Wang $L$, editor. Sustainable bioenergy production. Boca Raton: CRC Press; 2014. p. 263-83.

4. Khan D, Kumar A, Samadder SR. Impact of socioeconomic status on municipal solid waste generation rate. Waste Manag. 2016;49:15-25.

5. Jha AK, Li J, Nies L, Zhang L. Research advances in dry anaerobic digestion process of solid organic wastes. Afr J Biotechnol. 2011;10:14242-53.

6. Mmereki D, Baldwin A, Li B. A comparative analysis of solid waste management in developed, developing and lesser developed countries. Environ Technol Rev. 2016;5:120-41.

7. Kirama A, Mayo AW. Challenges and prospects of private sector participation in solid waste management in Dar es Salaam City. Tanzania Habitat Int. 2016:53:195-205.

8. Olabode AD, Lawrence A. Environmental impact of indiscriminate waste disposal on river channel in part of Akoko-region, Ondo state. Nigeria Int J Innov Sci Res. 2014:5:162-8.

9. Guerrero LA, Maas G, Hogland W. Solid waste management challenges for cities in developing countries. Waste Manag. 2013;33:220-32.

10. Dladla I, Machete F, Shale K. A review of factors associated with indiscriminate dumping of waste in eleven African countries. Afr J Sci Technol In. 2016:8:475-81.

11. Hoornweg D, Bhada-Tata P. What a waste: a global review of solid waste management. Washington, DC: World Bank; 2012.

12. Aziale LK, Asafo-Adjei E. Logistic challenges in urban waste management in Ghana a case of Tema metropolitan assembly. Eur J Bus Manage. 2013;5: 116-28.

13. Kazuva E, Zhang JQ. Analyzing municipal solid waste treatment scenarios in rapidly urbanizing cities in developing countries: the case of Dar Es Salaam. Tanzania Int J Env Res Pub He. 2019;16:2035.

14. dos Muchangos LS, Liu Y, Li B. Comparative study on municipal solid waste management systems of Maputo City, Mozambique and Chongqing City, China. Afr J Sci Technol Innov Dev. 2014;6:323-31. 
15. Loboka MK, Qi S, Celestino JL, Hassan SO, Wani S. Municipal solid waste management practices and fecal coliform water contamination in the cities of the developing countries: the case of juba. South Sudan Int J Environ Sci. 2013;3:1614-24.

16. De S, Debnath B. Prevalence of health hazards associated with solid waste disposal - a case study of Kolkata, India. In: International Conference on Solid Waste Management (5IconSWM 2015). Bangalore: Elsevier B.V; 2015.

17. Karak T, Bhagat RM, Bhattacharyya P. Municipal solid waste generation, composition, and management: the world scenario. Crit Rev Environ Sci Technol. 2012;42:1509-630.

18. Zhang DQ, Keat TS, Gersberg RM. A comparison of municipal solid waste management in Berlin and Singapore. Waste Manag. 2010;30:921-33.

19. Mohee R, Mauthoor S, Bundhoo ZMA, Somaroo G, Soobhany N, Gunasee S. Current status of solid waste management in small island developing states: a review. Waste Manag. 2015;43:539-49.

20. Aleluia J, Ferrao P. Characterization of urban waste management practices in developing Asian countries: a new analytical framework based on waste characteristics and urban dimension. Waste Manag. 2016;58:415-29.

21. Tan ST, Ho WS, Hashim H, Lee CT, Taib MR, Ho CS. Energy, economic and environmental (3E) analysis of waste-to-energy (WTE) strategies for municipal solid waste (MSW) management in Malaysia. Energ Convers Manage. 2015;102:111-20.

22. Mboowa D, Quereshi S, Bhattacharjee C, Tonny K, Dutta S. Qualitative determination of energy potential and methane generation from municipal solid waste (MSW) in Dhanbad (India). Energy. 2017;123:386-91.

23. Hla SS, Roberts D. Characterisation of chemical composition and energy content of green waste and municipal solid waste from greater Brisbane. Australia Waste Manage. 2015;41:12-9.

24. Omari AM, Kichonge BN, John GR, Njau KN, Mtui PL. Potential of municipal solid waste, as renewable energy source a case study of Arusha, Tanzania. Int J Renew Energ Tech Res. 2014;3:1-9.

25. Khamala EM, Alex AA. Municipal solid waste composition and characteristics relevant to the waste-to-energy disposal method for Nairobi city. Glob J Eng Des Tech. 2013;2:1-6.

26. Eddine BT, Salah MM. Solid waste as renewable source of energy: current and future possibility in Algeria. Int J Energy Environ Eng. 2012;3:17.

27. Dangi MB, Pretz CR, Urynowicz MA, Gerow KG, Reddy JM. Municipal solid waste generation in Kathmandu. Nepal J Environ Manage. 2011;92:240-9.

28. Bayard R, Morais JD, Ducom G, Achour F, Rouez M, Gourdon R. Assessment of the effectiveness of an industrial unit of mechanical-biological treatment of municipal solid waste. J Hazard Mater. 2010;175:23-32.

29. Mir MA, Hussain A, Verma C. Design considerations and operational performance of anaerobic digester: a review. Cogent Eng. 2016;3:1181696.

30. Mishra S, Singh PK, Dash S, Pattnaik R. Microbial pretreatment of lignocellulosic biomass for enhanced biomethanation and waste management. 3 Biotech. 2018;8:458.

31. Liew LN, Shi J, Li YB. Enhancing the solid-state anaerobic digestion of fallen leaves through simultaneous alkaline treatment. Bioresour Technol. 2011; 102:8828-34.

32. Marin J, Kennedy KJ, Eskicioglu C. Effect of microwave irradiation on anaerobic degradability of model kitchen waste. Waste Manag. 2010;30: 1772-9.

33. Zhou MM, Yan BH, Wong JWC, Zhang Y. Enhanced volatile fatty acids production from anaerobic fermentation of food waste: a mini-review focusing on acidogenic metabolic pathways. Bioresour Technol. 2018;248: 68-78.

34. Izumi K, Okishio YK, Nagao N, Niwa C, Yamamoto S, Toda T. Effects of particle size on anaerobic digestion of food waste. Int BiodeterBiodegr. 2010;64:601-8

35. Amiri L, Abdoli MA, Gitipour S, Madadian E. The effects of co-substrate and thermal pretreatment on anaerobic digestion performance. Environ Technol. 2017;38:2352-61.

36. Forgacs G, Pourbafrani M, Niklasson C, Taherzadeh MJ, Hovath IS. Methane production from citrus wastes: process development and cost estimation. J Chem Technol Biotechnol. 2012;87:250-5.

37. Alqaralleh $R$, Delatolla R, Kennedy K. Anaerobic digestion of simulatedorganic fraction of municipal solid waste: effect of alkaline pretreatment. Int J Environ Waste Manag. 2015;16:166-85.

38. Mackulak T, Prousek J, Svorc L, Drtil M. Increase of biogas production from pretreated hay and leaves using wood-rotting fungi. Chem Pap. 2012;66: 649-53.
39. Zhao J, Zheng Y, Li YB. Fungal pretreatment of yard trimmings for enhancement of methane yield from solid-state anaerobic digestion. Bioresour Technol. 2014;156:176-81.

40. Capson-Tojo G, Moscoviz R, Ruiz D, Santa-Catalina G, Trably E, Rouez M, et al. Addition of granular activated carbon and trace elements to favor volatile fatty acid consumption during anaerobic digestion of food waste. Bioresour Technol. 2018;260:157-68.

41. Amha YM, Anwar MZ, Brower A, Jacobsen CS, Stadler LB, Webster TM, et al. Inhibition of anaerobic digestion processes: applications of molecular tools. Bioresour Technol. 2018;247:999-1014.

42. Atasoy M, Owusu-Agyeman I, Plaza E, Cetecioglu Z. Bio-based volatile fatty acid production and recovery from waste streams: current status and future challenges. Bioresour Technol. 2018;268:773-86.

43. Jiang JG, Zhang YJ, Li KM, Wang Q, Gong CX, Li ML. Volatile fatty acids production from food waste: effects of $\mathrm{pH}$, temperature, and organic loading rate. Bioresour Technol. 2013;143:525-30.

44. Akuzawa $M$, Hori $T$, Haruta $S$, Ueno $Y$, Ishii M, Igarashi Y. Distinctive responses of metabolically active microbiota to acidification in a thermophilic anaerobic digester. Microb Ecol. 2011;61:595-605.

45. Vögeli Y, Lohri CR, Gallardo A, Diener S, Zurbrügg C. Anaerobic digestion of biowaste in developing countries: practical information and case studies. Dübendorf: Swiss Federal Institute of Aquatic Science and Technology; 2014.

46. Zhang AL, Shen J, Ni YH. Anaerobic digestion for use in the pulp and paper industry and other sectors: an introductory mini-review. BioResources. 2015; 10:8750-69.

47. Ye JQ, Li D, Sun YM, Wang GH, Yuan ZH, Zhen F, et al. Improved biogas production from rice straw by co-digestion with kitchen waste and pig manure. Waste Manag. 2013;33:2653-8.

48. Xu ZY, Zhao MX, Miao HF, Huang ZX, Gao SM, Ruan WQ. In situ volatile fatty acids influence biogas generation from kitchen wastes by anaerobic digestion. Bioresour Technol. 2014;163:186-92.

49. Zhang $L$, Jahng D. Long-term anaerobic digestion of food waste stabilized by trace elements. Waste Manag. 2012;32:1509-15.

50. Wei QY, Zhang WQ, Guo JB, Wu SB, Tan TW, Wang F, et al. Performance and kinetic evaluation of a semi-continuously fed anaerobic digester treating food waste: effect of trace elements on the digester recovery and stability. Chemosphere. 2014;117:477-85.

51. Zhang WQ, Wu SB, Guo JB, Zhou J, Dong RJ. Performance and kinetic evaluation of semi-continuously fed anaerobic digesters treating food waste: role of trace elements. Bioresour Technol. 2015;178:297-305.

52. Zhang WL, Xing WL, Li RD. Real-time recovery strategies for volatile fatty acid-inhibited anaerobic digestion of food waste for methane production. Bioresour Technol. 2018:265:82-92.

53. Banks CJ, Zhang Y, Jiang $Y$, Heaven S. Trace element requirements for stable food waste digestion at elevated ammonia concentrations. Bioresour Technol. 2012;104:127-35.

54. Zhang L, Lee YW, Jahng D. Anaerobic co-digestion of food waste and piggery wastewater: focusing on the role of trace elements. Bioresour Technol. 2011;102:5048-59.

55. Zhang CS, Xiao G, Peng LY, Su HJ, Tan TW. The anaerobic co-digestion of food waste and cattle manure. Bioresour Technol. 2013;129:170-6.

56. Lee JY, Lee SH, Park HD. Enrichment of specific electro-active microorganisms and enhancement of methane production by adding granular activated carbon in anaerobic reactors. Bioresour Technol. 2016; 205:205-12.

57. Xu SY, Han RQ, Zhang YC, He CQ, Liu HB. Differentiated stimulating effects of activated carbon on methanogenic degradation of acetate, propionate and butyrate. Waste Manag. 2018;76:394-403.

58. Dang Y, Sun DZ, Woodard TL, Wang LY, Nevin KP, Holmes DE. Stimulation of the anaerobic digestion of the dry organic fraction of municipal solid waste (OFMSW) with carbon-based conductive materials. Bioresour Technol. 2017;238:30-8

59. Cesaro A, Belgiorno V. Pretreatment methods to improve anaerobic biodegradability of organic municipal solid waste fractions. Chem Eng J. 2014;240:24-37.

60. Jain S, Jain S, Wolf IT, Lee J, Tong YW. A comprehensive review on operating parameters and different pretreatment methodologies for anaerobic digestion of municipal solid waste. Renew SustEnerg Rev. 2015;52:142-54.

61. Behera S, Arora R, Nandhagopal N, Kumar S. Importance of chemical pretreatment for bioconversion of lignocellulosic biomass. Renew SustEnerg Rev. 2014;36:91-106. 
62. Wagner AO, Lackner N, Mutschlechner M, Prem EM, Markt R, Illmer P. Biological pretreatment strategies for second-generation lignocellulosic resources to enhance biogas production. Energies. 2018;11:1797.

63. Feng XM, Karlsson A, Svensson BH, Bertilsson S. Impact of trace element addition on biogas production from food industrial waste linking process to microbial communities. FEMS Microbiol Ecol. 2010;74:226-40.

64. Hagos K, Zong JP, Li DX, Liu C, Lu XH. Anaerobic co-digestion process for biogas production: progress, challenges and perspectives. Renew SustEnerg Rev. 2017;76:1485-96.

65. Xie SH, Hai Fl, Zhan XM, Guo WS, Ngo HH, Price WE, et al. Anaerobic codigestion: a critical review of mathematical modelling for performance optimization. Bioresour Technol. 2016;222:498-512.

66. Liu FH, Rotaru AE, Shrestha PM, Malvankar NS, Nevin KP, Lovley DR. Promoting direct interspecies electron transfer with activated carbon. Energy Environ Sci. 2012;5:8982-9.

67. Wang K, Yin J, Shen DS, Li N. Anaerobic digestion of food waste for volatile fatty acids (VFAs) production with different types of inoculum: effect of $\mathrm{pH}$. Bioresour Technol. 2014;161:395-401.

68. Baek G, Kim J, Kim J, Lee C. Role and potential of direct interspecies electron transfer in anaerobic digestion. Energies. 2018;11:107.

69. Luo CH, Lu F, Shao LM, He PJ. Application of eco-compatible biochar in anaerobic digestion to relieve acid stress and promote the selective colonization of functional microbes. Water Res. 2015;68:710-8.

70. Fagbohungbe MO, Herbert BMJ, Hurst L, Ibeto CN, Li H, Usmani SQ, et al. The challenges of anaerobic digestion and the role of biochar in optimizing anaerobic digestion. Waste Manag. 2017;61:236-49.

71. Rajagopal R, Masse DI, Singh G. A critical review on inhibition of anaerobic digestion process by excess ammonia. Bioresour Technol. 2013;143:632-41.

72. Dai XH, Yan H, Li N, He J, Ding YL, Dai LL, et al. Metabolic adaptation of microbial communities to ammonium stress in a high solid anaerobic digester with dewatered sludge. Sci Rep-UK. 2016;6:28193.

73. Prochazka J, Dolejs P, Maca J, Dohanyos M. Stability and inhibition of anaerobic processes caused by insufficiency or excess of ammonia nitrogen. Appl Microbiol Biotechnol. 2012;93:439-47.

74. Ji ZG. Water quality and eutrophication. Hydrodynamics and water quality. 2nd ed. Hoboken: Wiley; 2017. p. 161-271.

75. Dadaser-Celik F, Azgin ST, Yildiz YS. Optimization of solid content, carbon/ nitrogen ratio and food/inoculum ratio for biogas production from food waste. Waste Manag Res. 2016;34:1241-8.

76. Khalid A, Arshad M, Anjum M, Mahmood T, Dawson L. The anaerobic digestion of solid organic waste. Waste Manag. 2011;31:1737-44.

77. Sun C, Cao WX, Banks CJ, Heaven S, Liu RH. Biogas production from undiluted chicken manure and maize silage: a study of ammonia inhibition in high solids anaerobic digestion. Bioresour Technol. 2016;218:1215-23.

78. Divya D, Gopinath LR, Christy PM. A review on current aspects and diverse prospects for enhancing biogas production in sustainable means. Renew SustEnerg Rev. 2015;42:690-9.

79. UN. World Population Prospects: The 2017 Revision, key findings and advance tables. New York: United Nations. p. 2017.

80. Surendra KC, Takara D, Hashimoto AG, Khanal SK. Biogas as a sustainable energy source for developing countries: opportunities and challenges. Renew SustEnerg Rev. 2014;31:846-59.

81. Rasi S, Veijanen A, Rintala J. Trace compounds of biogas from different biogas production plants. Energy. 2007;32:1375-80.

82. Tumwesige V, Fulford D, Davidson GC. Biogas appliances in sub-Sahara Africa. Biomass Bioenergy. 2014;70:40-50.

83. Shen YW, Linville JL, Urgun-Demirtas M, Mintz MM, Snyder SW. An overview of biogas production and utilization at full-scale wastewater treatment plants (WWTPS) in the United States: challenges and opportunities towards energy-neutral WWTPs. Renew SustEnerg Rev. 2015;50:346-62.

84. Nghiem LD, Koch K, Bolzonella D, Drewes JE. Full-scale co-digestion of wastewater sludge and food waste: bottlenecks and possibilities. Renew SustEnerg Rev. 2017;72:354-62.

85. Al-Hamamre Z, Saidan M, Hararah M, Rawajfeh K, Alkhasawneh HE, AlShannag M. Wastes and biomass materials as sustainable-renewable energy resources for Jordan. Renew SustEnerg Rev. 2017;67:295-314.

86. Laks R. The potential for electricity generation from biogas in South Africa: a potential study as part of the BAPEPSA project. Petten: ECN; 2017.

87. Patrizio P, Leduc S, Chinese D, Dotzauer E, Kraxner F. Biomethane as transport fuel - a comparison with other biogas utilization pathways in northern Italy. Appl Energy. 2015;157:25-34.
88. Uchytil P, Schauer J, Petrychkovych R, Setnickova K, Suen SY. Ionic liquid membranes for carbon dioxide-methane separation. J Membr Sci. 2011;383:262-71.

89. Bakonyi P, Nemestothy N, Belafi-Bako K. Biohydrogen purification by membranes: an overview on the operational conditions affecting the performance of non-porous, polymeric and ionic liquid based gas separation membranes. Int J Hydrogen Energ. 2013;38:9673-87.

90. Raimi A, Adeleke R, Roopnarain A. Soil fertility challenges and Biofertiliser as a viable alternative for increasing smallholder farmer crop productivity in sub-Saharan Africa. Cogent Food Agr. 2017;3:1400933.

91. Koszel M, Lorencowicz E. Agricultural use of biogas digestate as a replacement fertilizers. Agric Agric Sci Proc. 2015;7:119-24.

92. Semiyaga S, Okure MAE, Niwagaba CB, Katukiza AY, Kansiime F. Decentralized options for faecal sludge management in urban slum areas of sub-Saharan Africa: a review of technologies, practices and end-uses. ResourConservRecy. 2015;104:109-19.

93. Mukhubau M, Roopnarain A, Adeleke R, Moeletsi M, Makofane R. Comparative assessment of bio-fertiliser quality of cow dung and anaerobic digestion effluent. Cogent Food Agr. 2018;4:1435019.

94. Islam MR, Rahman SME, Rahman MM, Oh DH, Ra CS. The effects of biogas slurry on the production and quality of maize fodder. Turk J Agric For. 2010;34:91-9.

95. Makádi M, Tomócsik A, Orosz V. Digestate: a new nutrient source - review. In: Kumar S, editor. Biogas. Rijeka: InTech; 2012. p. 295-310.

96. Bonten LTC, Zwart KB, Rietra RPJJ, Postma R, de Haas MJG. Bio-slurry as fertilizer: is bio-slurry from household digesters a better fertilizer than manure? A literature review. Alterra Wageningen UR: Wageningen; 2014

97. Torres-Climent A, Martin-Mata J, Marhuenda-Egea F, Moral R, Barber X, Perez-Murcia MD, et al. Composting of the solid phase of digestate from biogas production: optimization of the moisture, $\mathrm{C} / \mathrm{N}$ ratio, and $\mathrm{pH}$ conditions. Commun Soil Sci Plan. 2015;46:197-207.

98. Alburquerque JA, de la Fuente C, Ferrer-Costa A, Carrasco L, Cegarra J, Abad $\mathrm{M}$, et al. Assessment of the fertiliser potential of digestates from farm and agroindustrial residues. Biomass Bioenergy. 2012;40:181-9.

99. Nkoa R. Agricultural benefits and environmental risks of soil fertilization with anaerobic digestates: a review. Agron Sustain Dev. 2014;34:473-92.

100. Kratzeisen M, Starcevic N, Martinov M, Maurer C, Muller J. Applicability of biogas digestate as solid fuel. Fuel. 2010;89:2544-8.

101. Zurbrugg C, Caniato M, Vaccari M. How assessment methods can support solid waste management in developing countries - a critical review. Sustainability-Basel. 2014;6:545-70.

102. De Medina-Salas L, Castillo-Gonzalez E, Giraldi-Diaz MR, Guzman-Gonzalez V. Analysis of economical and environmental costs for the selection of municipal solid waste treatment and disposal scenarios through multicriteria analysis (ELECTRE method). Sustainability-Basel. 2017;9:1758.

103. Maalouf A, El-Fadel M. Effect of a food waste disposer policy on solid waste and wastewater management with economic implications of environmental externalities. Waste Manag. 2017;69:455-62.

104. Qazi WA, Abushammala MFM, Azam MH. Multi-criteria decision analysis of waste-to-energy technologies for municipal solid waste management in Sultanate of Oman. Waste Manag Res. 2018;36:594-605.

\section{Publisher's Note}

Springer Nature remains neutral with regard to jurisdictional claims in published maps and institutional affiliations.

\section{Ready to submit your research? Choose BMC and benefit from:}

- fast, convenient online submission

- thorough peer review by experienced researchers in your field

- rapid publication on acceptance

- support for research data, including large and complex data types

- gold Open Access which fosters wider collaboration and increased citations

- maximum visibility for your research: over $100 \mathrm{M}$ website views per year

At BMC, research is always in progress.

Learn more biomedcentral.com/submissions 